\title{
Antibiotic resistance pattern of bacteria isolated from outdoor patients in Dhaka city: a single center study
}

\author{
Most. Salma Khatun, Saimun Nahar and Md. Shahidul Kabir* \\ Department of Microbiology, Stamford University Bangladesh, 51, Siddeswari Road, Dhaka-1217, Bangladesh
}

Received 05 March 2019/Accepted 07 April 2019

\begin{abstract}
Bacterial infections are often found to cause morbidity and mortality around the globe. Indiscriminate use of antibiotic for treatment of such infections is reported to cause selective pressure and increase in drug resistance. Emergence of antibiotic resistance is a growing concern for people of all age having bacterial infections. It is important to determine the trend of antibiotic resistance patterns of pathogenic bacteria isolated from clinical samples for appropriate treatment of patients. A retrospective study was conducted on patient samples collected from 1 July 2018 to 15 March 2019. A total of 500 urine, 136 blood, 120 stool, 172 swab, 90 Sputum and 60 pus samples were randomly collected from both male and female patients of different age groups who reported to a diagnostic centre in Dhaka city. Pathogenic bacteria were isolated and identified from the collected samples following standard methods. Antibiotic sensitivity patterns of isolated bacteria were also determined by disc diffusion test. Proportion of UTI in female patients $(\mathbf{7 1 . 6 7 \%}$ ) was found to be higher than the male $(\mathbf{2 8 . 3 3 \%})$ patients and mostly caused by Escherichia coli (73.33\%). Among Gram negative bacteria, $E$. coli $(51 \%)$ was found to be predominant followed by Pseudomonas spp. (11.47\%), Klebsiella $(\mathbf{9 . 8 4 \%})$ and Salmonella Typhi $(\mathbf{9 . 8 4 \%})$. Among Gram positive organism Staphylococcus aureus $(\mathbf{9 . 0 \%})$, beta haemolytic streptococci $(5.74 \%)$ and enterococci $(3.28 \%)$ were found to be present. Among the tested antibiotics imipenem was found to be the most effective $(93.02 \%)$ followed by gentamycin (76.03\%) against all isolated bacteria. Amoxycillin was found to be least effective (21.29\%) against all isolated bacteria. Increase in antibiotic resistance was possibly due to indiscriminate use of antibiotic for treatment of various infections. Prudent use of antimicrobial drugs will help reduce spread of resistant bacteria and complication of treatment of infected patients.
\end{abstract}

Keywords: Pathogenic bacteria, Antibiotic resistance, Outdoor patients.

\section{INTRODUCTION}

Throughout the history of human civilization microbial infections have played a critical role in human survival and death. Bacterial infections are important causes of fatality in the globe and increase in the antibiotic resistant bacteria due to challenge with antibiotic therapy is a growing public health concern (1-3). Urinary tract infections (UTIs), blood stream infections (BSIs), wound infections, diarrheal diseases and enteric infections are common bacterial infections in human population. UTIs after respiratory tract infections are the most common infectious diseases and nearly $10 \%$ of the global population experiences such infections in their lifetime (4). It is also one of the most frequently occurring nosocomial infections (5). Approximately 150 million UTI cases are reported every year throughout the world (6). The clinical manifestations of UTI depend on the part of the urinary tract involved, the etiologic organisms, the severity of the infection and the patient's ability to mount an immune response to it (7). UTIs are more common in females than in males. In males the anatomical length of the urethra $(20 \mathrm{~cm})$ provides a distance barrier that excludes microorganisms from the urinary bladder. Conversely, the short urethra
$(5 \mathrm{~cm})$ in females is more readily transverse by microorganisms. In women, the urethra is much shorter and very close to the anus, which is a constant source of fecal bacteria (8). Some studies have shown that the urinary pathogens such as E. coli, Klebsiella, Pseudomonas and Enterococcus species are the main causes of UTI in the community (9). In most cases, empirical antimicrobial therapy is prescribed and for this purpose, it is extremely important to know the main bacteria which are involved in the UTI and their antimicrobial resistance patterns $(10,11)$. Blood stream infections (BSIs) are one of the most common nosocomial infections which occur with high morbidity and mortality in the world (12). As BSIs among patients in intensive care units (ICUs) are usually secondary to intravascular catheters, they can be caused by both gram-positive and gram-negative microorganisms as well as fungi. Blood culture (BC) is one of the most important tools for their diagnosis. The timely and suitable use of antibiotics is the only way for treatment of bacteremia, however many of the bacterial pathogens are becoming resistant to the antimicrobial agents (12). Wound-infection is one of the crucial health problems caused by the invasion of pathogenic microbes. Both gram-positive and gramnegative bacteria are associated with wound- 
infections. In a number of previous reports $S$. aureus, P. aeruginosa, Proteus vulgaris, Proteus mirabilis, Enterococcus spp., Enterobacter spp. and Acinetobacter spp. were found to be associated with wound-infections (13-18). Diarrheal diseases and enteric infections are the major causes of morbidity and mortality in developing countries resulting in over quarter of all childhood death. Globally Salmonella and Shigella remain as the major causative agents associated with acute enteric infections, with nontyphoid Salmonella isolated in increasing number from diverse geographic regions (19). Human infections can be caused by Salmonella species by ingestion of contaminated food and water. The purpose of this study was to isolate and identify pathogenic bacteria from different clinical samples and to determine their susceptibility to commonly prescribed antibiotics which may help the physician to choose appropriate treatment for the prevention of blood stream, wound, enteric and urinary tract infections.

\section{MATERIALS AND METHODS}

Collection of samples. The mid-stream of early morning urine samples were collected from patients reported to a renowned diagnostic center in Dhaka city. Blood, stool, swab, sputum and pus samples were also collected from the same institution. A total of 1078 samples, comprising of 500 urine, 136 blood, 120 stool, 172 swab, 90 sputum and 60 pus samples, were randomly collected from both male and female patients of all ages reported to the centre.

Isolation of pathogenic bacteria. A measured loop was used to streak $10 \mu \mathrm{l}$ of sample separately on Blood agar (BA) and MacConkey agar (MA) for al urine samples. Blood, pus and sputum samples were placed on BA, MA and Chocholate agar (CA). Stool samples were placed on MA, Salmonella Shigella (SS) agar and Thiosulfate Citrate Bile salt Sucrose (TCBS) agar after appropriate enrichment. All suspected isolated colonies were identified using standard biochemical tests (20).

Identification of isolated bacteria. Biochemical test were done depending on the type of isolated bacteria (gram-positive and gram-negative) from various samples. In order to identify gram-positive bacteria catalase, coagulase, optochin disk and CAMP tests were done. Gram-negative bacteria were tested for methyl red, motility, oxidase, citrate production and growth on Kligler's Iron Agar (21).

Antibiotic susceptibility test. Antimicrobial susceptibility test of isolates was performed on Mueller Hinton agar by modified disk diffusion method according to Clinical and Laboratory Standards Institute (CLSI) guideline (22). Different antibiotic discs were used to observe the antibiotic sensitivity of the test organisms as described by Kirby Bauer (23). Commercially available antibiotic discs ampicillin $10 \mu \mathrm{g}(\mathrm{AM})$, ciprofloxacin $5 \mu \mathrm{g}$ (CIP), gentamycin $10 \mu \mathrm{g}(\mathrm{GM})$, ofloxacin $5 \mu \mathrm{g}(\mathrm{OF})$, pefloxacin $5 \mu \mathrm{g}(\mathrm{PF})$, cotrimoxazole $25 \mu \mathrm{g}$ (COT), imipenem $10 \mu \mathrm{g}$ (IMP), Ceftriaxone $30 \mu \mathrm{g}$ (CRO) ceftazidime $30 \mu \mathrm{g}(\mathrm{CAZ})$, mecillinam $10 \mu \mathrm{g}$ (MCL), aztreonam $30 \mu \mathrm{g}$ (ATM) were used in this study.

\section{RESULTS}

In this study, 1078 samples from different clinical specimens were collected and analyzed. From 1078 samples, 500 were obtained from urine, 172 from swab, 136 from blood, 120 from stool, 90 from sputum and 60 from pus. Among the samples screened, 122 (11.32\%) showed positive in culture test, comprising of 60 isolates from urine, 20 isolates from swab, 12 isolates from blood, 5 isolates from stool, 5 isolates from sputum and 20 isolates from pus. Of these 60 urine positive cases, $71.67 \%$ were female and $28.33 \%$ were male samples. Gram-negative bacilli isolated accounted for $96.67 \%$ of the positive cultures, while Gram-positive enterococci were
S. epidermidis, MRSA, E. coli, K. pneumoniae, $3.33 \%$. The most common isolates from urine in this study have been the gram-negative bacilli which account for $81.97 \%$ of the total positive isolates. Among the gram-negative bacilli, the predominant isolate was E. coli $73.33 \%$ followed by other bacilli such as Klebsielle spp. $16.67 \%$ and Pseudomonas $6.67 \%$. Within gram-positive bacteria only enterococci $3.33 \%$ was found to cause UTIs. Antibiotic susceptibility test was performed by modified disk diffusion method (23). Table 1 shows the overall sensitivity pattern of isolated bacteria from urine samples that fall under both gram-positive and gram-negative bacteria. Table 2 shows a range of gram-negative bacteria obtained from different samples that include E. coli, Klebsiella, Pseudomonas and Salmonella Typhi. Staphylococcus aureus, beta haemolytic streptococci and enterococci were also isolated from Gram positive type. Among Gram negative bacteria the $E$. coli is the most predominant bacteria followed by Pseudomonas, Klebsiella and Salmonella Typhi.

Table 1. Antibiotic sensitivity pattern of urine isolates.

\begin{tabular}{|c|c|c|c|c|c|}
\hline Antibiotic & : & $\therefore \frac{2}{8}$ & 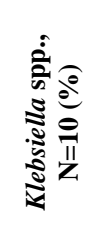 & 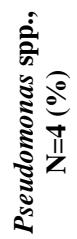 & 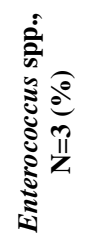 \\
\hline \multirow[t]{2}{*}{ Ampicillin } & $\mathrm{S}$ & $0(0)$ & 0 & N/D & $2(100)$ \\
\hline & $\mathrm{R}$ & $44(100)$ & $10(100)$ & N/D & 0 \\
\hline \multirow[t]{2}{*}{ Ceftiaxone } & $\mathrm{S}$ & $24(54.55)$ & $5(50)$ & $2(50)$ & $1(50)$ \\
\hline & $\mathrm{R}$ & $20(45.45)$ & $5(50)$ & $2(50)$ & $1(50)$ \\
\hline \multirow[t]{2}{*}{ Ciprofloxacin } & $\mathrm{S}$ & $17(38.63)$ & $7(70)$ & $2(50)$ & 0 \\
\hline & $\mathrm{R}$ & $27(61.36)$ & $3(30)$ & $2(50)$ & $2(100)$ \\
\hline $\mathrm{Co}-$ & $\mathrm{S}$ & $15(34)$ & $5(50)$ & N/D & 0 \\
\hline Trimoxazole & $\mathrm{R}$ & $29(66)$ & $5(50)$ & N/D & $2(100)$ \\
\hline \multirow[t]{2}{*}{ Ceftazidime } & $\mathrm{S}$ & $23(52.27)$ & $6(60)$ & $3(75)$ & $1(50)$ \\
\hline & $\mathrm{R}$ & $21(47.73)$ & $4(40)$ & $1(25)$ & $1(50)$ \\
\hline \multirow[t]{2}{*}{ Gentamycin } & $\mathrm{S}$ & $32(72.73)$ & $9(90)$ & $3(75)$ & $1(50)$ \\
\hline & $\mathrm{R}$ & $12((27.27)$ & $1(10)$ & $1(25)$ & $1(50)$ \\
\hline \multirow[t]{2}{*}{ Mecillinam } & $\mathrm{S}$ & $40((90.90)$ & $8(80)$ & N/D & $1(50)$ \\
\hline & $\mathrm{R}$ & $4(9.10)$ & $2(20)$ & N/D & $1(50)$ \\
\hline \multirow[t]{2}{*}{ Imipenem } & $\mathrm{S}$ & $43(97.73)$ & $10(100)$ & $2(50)$ & $2(100)$ \\
\hline & $\mathrm{R}$ & $1(2.27)$ & $0(0)$ & $2(50)$ & 0 \\
\hline \multirow[t]{2}{*}{ Aztreonam } & $\mathrm{S}$ & $22(50)$ & $2(20)$ & $3(75)$ & 0 \\
\hline & $\mathrm{R}$ & $22(50)$ & $8(80)$ & $1(25)$ & $2(100)$ \\
\hline \multirow[t]{2}{*}{ Ofloxacin } & $\mathrm{S}$ & $16(36.36)$ & $7(70)$ & $2(50)$ & 0 \\
\hline & $\mathrm{R}$ & $28(63.64)$ & $3(30)$ & $2(50)$ & $2(100)$ \\
\hline \multirow[t]{2}{*}{ Pefloxacin } & $\mathrm{S}$ & $15(34)$ & $7(70)$ & $2(50)$ & 0 \\
\hline & $\mathrm{R}$ & $29(66)$ & $3(30)$ & $2(50)$ & $2(100)$ \\
\hline
\end{tabular}

N.B: N/D = Not Done

Antibiotic sensitivity patterns of all isolates from different samples are shown in Table 3. Antibiotic sensitivity patterns of E. coli, Pseudomonas, Klebsiella, Salmonella Typhi., Staphylococcus aureus, beta haemolytic streptococci and enterococci isolated from different samples against several different antibiotics are shown here. 
Table 2. Distribution of gram-positive and gram-negative bacteria isolated from different samples

\begin{tabular}{c|cccc|ccc}
\hline \multirow{2}{*}{ Sample } & \multicolumn{4}{|c|}{ Gram negative bacteria } & \multicolumn{3}{c}{ Gram positive bacteria } \\
& E. coli & Klebsiella & Pseudomonas & S. Typhi & S. aureus & Beta. & Enterococci \\
\hline Urine & 44 & 10 & 4 & 0 & 0 & 0 & 2 \\
Blood & 0 & 0 & 0 & 12 & 0 & 0 & 0 \\
Swab & 4 & 0 & 2 & 0 & 8 & 6 & 0 \\
Stool & 5 & 0 & 0 & 0 & 0 & 0 & 0 \\
Sputum & 0 & 2 & 2 & 0 & 0 & 1 & 0 \\
Pus & 9 & 0 & 6 & 0 & 3 & 0 & 2 \\
& $62(51 \%)$ & $12(9.84 \%)$ & $14(11.47 \%)$ & $12(9.84 \%)$ & $11(9 \%)$ & $7(5.74 \%)$ & $4(3.28 \%)$ \\
\hline Total & \multicolumn{2}{c|}{$100(81.97 \%)$} & & $22(18.03 \%)$ \\
\hline
\end{tabular}

N.B: Beta $=$ beta haemolytic streptococci; S. aureus $=$ Staphylococcus aureus; $S$. Typhi $=$ Salmonella Typhi

Table 3. Antibiotic sensitivity pattern of isolated bacteria from all isolates

\begin{tabular}{|c|c|c|c|c|c|c|c|c|}
\hline Antibiotics & $\mathbf{S}$ or $\mathbf{R}$ & 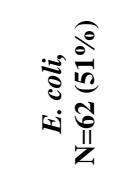 & 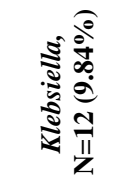 & 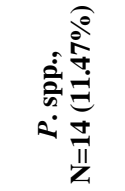 & 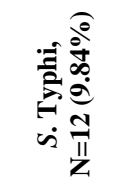 & 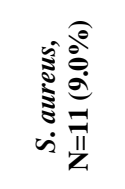 & 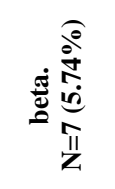 & 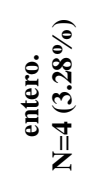 \\
\hline \multirow[t]{2}{*}{ Ampicillin } & $\mathrm{S}$ & 0 & 0 & N/D & 11(91.67) & $1(9.10)$ & $7(100)$ & $4(100)$ \\
\hline & $\mathrm{R}$ & $62(100)$ & $12(100)$ & N/D & $1(8.33)$ & $10(90.90)$ & 0 & 0 \\
\hline \multirow[t]{2}{*}{ Ceffriaxone } & $\mathrm{S}$ & $37(59.68)$ & $7(58.34)$ & $6(46.16)$ & $12(100)$ & $11(100)$ & $7(100)$ & $3(75)$ \\
\hline & $\mathrm{R}$ & $25(40.32)$ & $5(41.66)$ & $7(53.84)$ & 0 & 0 & 0 & $1(25)$ \\
\hline \multirow[t]{2}{*}{ Ciprofloxacin } & $\mathrm{S}$ & $32(51.62)$ & $9(75)$ & $5(38.46)$ & $12(100)$ & $6(54.55)$ & $2(28.57)$ & $2(50)$ \\
\hline & $\mathrm{R}$ & $30(48.38)$ & $3(25)$ & $8(62.54)$ & 0 & $5(45.45)$ & $5(71.43)$ & $2(50)$ \\
\hline \multirow[t]{2}{*}{ Co- Trimoxazole } & $\mathrm{S}$ & $29(46.78)$ & $7(58.34)$ & N/D & $11(91.67)$ & $11(100)$ & 0 & $1(25)$ \\
\hline & $\mathrm{R}$ & $33(53.22)$ & $5(41.66)$ & N/D & $1(8.33)$ & 0 & $7(100)$ & $3(75)$ \\
\hline \multirow[t]{2}{*}{ Ceftazidime } & $\mathrm{S}$ & $30(52.63)$ & $8(66.67)$ & $7(53.84)$ & $12(100)$ & N/D & $\mathrm{N} / \mathrm{D}$ & $3(75)$ \\
\hline & $\mathrm{R}$ & $27(47.37)$ & $4(33.33)$ & $6(46.16)$ & 0 & N/D & N/D & $1(25)$ \\
\hline \multirow[t]{2}{*}{ Gentamycin } & $\mathrm{S}$ & $46(74.20)$ & $11(91.67)$ & $7(53.84)$ & $12(100)$ & $11(100)$ & $3(42.86)$ & $2(50)$ \\
\hline & $\mathrm{R}$ & $16(25.80)$ & $1(8.33)$ & $6(46.16)$ & 0 & 0 & $4(57.14)$ & $2(50)$ \\
\hline \multirow[t]{2}{*}{ Mecillinam } & $\mathrm{S}$ & $44(90)$ & $8(66.67)$ & N/D & N/D & N/D & N/D & $1(50)$ \\
\hline & $\mathrm{R}$ & $5(10)$ & $4(33.33)$ & N/D & N/D & N/D & N/D & $1(50)$ \\
\hline \multirow[t]{2}{*}{ Imipenum } & $\mathrm{S}$ & $54(94.74)$ & $12(100)$ & $10(76.93)$ & N/D & N/D & N/D & $4(100)$ \\
\hline & $\mathrm{R}$ & $3(5.26)$ & 0 & $3(23.07)$ & N/D & N/D & N/D & 0 \\
\hline \multirow[t]{2}{*}{ Aztreonam } & $\mathrm{S}$ & $31(54.39)$ & $4(33.33)$ & $7(53.84)$ & N/D & N/D & N/D & 0 \\
\hline & $\mathrm{R}$ & $26(45.61)$ & $8(66.67)$ & $6(46.16)$ & N/D & N/D & N/D & $4(100)$ \\
\hline \multirow[t]{2}{*}{ Ofloxacin } & $\mathrm{S}$ & $30(48.38)$ & $9(75)$ & $5(38.46)$ & $12(100)$ & $6(54.55)$ & $1(14.28)$ & $2(50)$ \\
\hline & $\mathrm{R}$ & $32(51.62)$ & $3(25)$ & $8(62.54)$ & 0 & $5(45.45)$ & $6(85.72)$ & $2(50)$ \\
\hline \multirow[t]{2}{*}{ Pefloxacin } & $\mathrm{S}$ & $30(48.38)$ & $9(75)$ & $4(30.77)$ & $11(91.67)$ & $6(54.55)$ & $1(14.28)$ & $2(50)$ \\
\hline & $\mathrm{R}$ & $32(51.62)$ & $3(25)$ & $9(69.23)$ & $1(8.33)$ & $5(45.45)$ & $6(85.72)$ & $2(50)$ \\
\hline
\end{tabular}

N.B: beta = beta haemolytic streptococci; $S$. aureus $=$ Staphylococcus aureus; $P$. spp= Pseudomonas $\mathrm{spp} . ; \mathrm{N} / \mathrm{D}=$ Not done; entero.= enterococci; $S$. Typhi= Salmonella Typhi; S=Sensitivity; R=Resistance.

\section{DISCUSSION}

The present study shows that $28.33 \%$ bacteria were isolated from male and the remaining $71.78 \%$ isolates were isolated from female (Fig.1). The sex distribution of patients in our study is consistent with those of other reported studies in our country showing a predominance of UTI in female patients $(71.78 \%)$. In another study researchers demonstrated that the rate of infection was three times higher in females than in males (24).

In agreement with previous report, our data shows that the prevalence of gram-negative bacteria $81.97 \%$ in different clinical infections was higher than grampositive bacteria $18.03 \% \quad$ (25). Culture based diagnosis of bacterial infections in a previous study showed that urinary tract infection was more prevalent than other infections. In the present study, imipenem was the most effective antibiotic against E. coli, Klebsiella, Pseudomonas and enterococci isolated from different samples (Table 3). In another study imipenem was also reported to be the most effective antibiotic against uropathogens (26). The result of this study is further supported by another study conducted in Japan where they reported sensitivity of uropathogens to imipenem from 93 to $100 \%$ (27). The low resistance rates detected for imipenem may be attributed to their uncommon use in the empirical treatment of UTIs, and the use of these antibiotics only in hospitalized patients according to culture 
results. In this study it was found that ceftriaxone and gentamycin were effective against gram-negative bacteria E. coli, Klebsiella, Pseudomonas and Salmonella Typhi, whereas ampicillin shows maximum resistance $(100 \%)$ against all gram-negative bacteria except Salmonella Typhi. In this study, ceftriaxone (95.45\%) and gentamycin (72.72\%) demonstrated high activity against gram-positive bacteria viz. Staphylococcus aureus, beta haemolytic streptococci and enterococci. Ceftriaxone showed higher antimicrobial activity than gentamycin against both gram-positive and gram-negative bacteria.

\section{CONCLUSION}

The resistance rate depends on local antibiotic prescription practice, improperly adjusted treatment dose or frequent use of antibiotics in the treatment of various infections. The appropriate use of antimicrobial drugs, control of spreading resistant bacteria and continuous monitoring and studies on the multidrug resistant bacteria will help maintain the effectiveness of antibiotics. A large number of samples could be analyzed in the future studies to determine the trend of antibiotic resistance patters of potential pathogens causing infections.

\section{REFERENCES}

1. Andersson D and Hughes D. 2011. Persistence of antibiotic resistance in bacterial populations. FEMS. Microbiol. Rev. 35:901-11.

2. Newman MJ, Frimpong E, Donkor ES, Opintan JA, Asamoah-Adu A and Asamoah-Adu A. 2011. Resistance to antimicrobial drugs in Ghana Infect. Drug Resist. 4:215-20.

3. Planson AG, Carbonell P, Grigoras I and Faulon JL. 2011. Engineering antibiotic production and overcoming bacterial resistance. Biotechnol. J. 6:812-25.

4. Farajnia S, Alikhani MY, Ghotaslou R, Naghili B and Nakhlband A. 2009. Causative agents and antimicrobial susceptibilities of urinary tract infections in the northwest of Iran. Int. J. Infect. Dis. 13:140-4.

5. Ronald AR, Nicolle LE and Stamm E. 2001. Urinary tract infection in adults: research priorities and strategies. Int. J. Antimicrob. Agents. 17: 343-8.

6. Karlowsky JA, Lagacé-Wiens PR, Simner PJ, DeCorby MR, Adam HJ and Walkty A, et al. 2011 Antimicrobial resistance in urinary tract pathogens in Canada from 2007 to 2009: CANWARD surveillance study. Antimicrob. Agents Chemother. 55:3169-75.

7. Foxman B. 2003. Epidemiology of urinary tract infections: Incidence, morbidity and economic costs. Dis. Mon. 49:53-70.

8. Zilevièa A. 2005. Hospital-acquired and Community- acquired Uropathogens, Modelling of Infection. Bioautomation. 3: 63-67.

9. Rahman F, Chowdhury S, Rahman MM, Ahmed D and Hossain A. 2009. Antimicrobial resistance pattern of gram-negative bacteria causing urinary tract infection. S. J. Pharma. Sci. 2:44-50.
10. De Francesco MA, Ravizzola G, Peroni L, Negrini R and Manca N. 2007. Urinary tract infection in Brescia, Italy: etiology of uropathogens and antimicrobial resistance of common uropathogens. Med. Sci. Monit. 13:1-7.

11. Linhares I, Raposo T, Rodrigues A and Almeida A. 2013. Frequency and antimicrobial resistance patterns of bacteria implicated in community urinary tract infections: a ten-year surveillance study. BMC. Infect. Dis. (2002-2009). 13:1-14.

12. Dagnew M, Yismaw G, Gizachew M, Gadisa A, Abebe T and Tadesse T. 2013. Bacterial profile and antimicrobial susceptibility pattern in septicemia suspected patients attending Gondar University Hospital, Northwest Ethiopia. BMC. Res. Notes. 6:283.

13. Rai S, Yadav UN and Pant ND. 2017. Bacteriological profile and antimicrobial susceptibility patterns of bacteria isolated from pus/wound swab samples from children attending a tertiary care hospital in Kathmandu. Nepal. Int. J. Microbiol. 2017:2529085.

14. Pokhrel P, Shrestha A, Panthi P, Manandhar S and Chaudhary DK. 2017. Bacteriological profile and antibiotic susceptibility pattern of would infection in children. E.C. Microbial. 5:93-100.

15. Raza MS, Chander A and Ranabhat A. 2013. Antimicrobial susceptibility patterns of the bacterial isolates in post-operative wound infection in a tertiary care hospital, Kathmandu, Nepal. Open J. Med. Microbiol. 3:159-63.

16. Shrestha S, Wenju P, Shrestha R and Karmacharya RM. 2016. Incidence and risk factors of surgical site infections in Kathmandu University Hospital, Kavre, Nepal. Kathmandu Uni. Med. J. 14:107-11

17. Shrestha A and Sharma VK. 2013. Bacteriological study of wound infection and antibiotic susceptibility pattern of the isolates. Nepal J. Sci. Tech. 14:143-50.

18. Gautam R, Acharya A, Nepal HP and Shrestha S. 2013. Antibiotic susceptibility pattern of bacterial isolates from wound infection in Chitwan Medical College Teaching Hospital, Chitwan, Nepal. Int. J. Biol. Adv. Res. 4:248-52.

19. Jousilahti P, S.M. Madkour, T. Ambrechts and E. Sherwin. 1997. Diarrheal disease morbidity and Home practices in Egypt. Public Health. 111:5-10.

20. Winn WC. 2006. Konemann's color atlas and diagnostic text of microbiology, 6th ed., p. 945-1021. Lippencott Williams \& Wilkins Publishers, Philadelphia, PA.

21. Cappuccino JG and Shannan N. 2005. Microbiology, A Laboratory Manual, Seventh edition. Pearson. P:143-179.

22. Cockeril FR, Wikler MA, Alder J, Dudley MN, Eliopoulos GM and Ferraro MJ et al. Natonal Committee for Clinical Laboratory Standards, Ed; "Performance Standards for antimicrobial disk susceptibility tests; twenty-second informational supplement $11^{\text {th }}$ ed," Approved Standards MO2-A11, Natonal Committee for Clinical Laboratory Standards, Wayne, PA, USA, 2012. 32:1-188.

23. Cappuccino JG and Shannan N. 2005. Microbiology, A Laboratory Manual, Seventh edition. Pearson. P:254

24. Shaqra A. 2000. Occurrence and antibiotic sensitivity of Enterobacteriaceae isolated from a group of Jordanian patients with community acquired urinary tract infections. Cytobios. 101:15-21.

25. Haghi Ashtiani MT, Mamishi S, Masoomi A, Nasiri N, Hosseini M and Nikmanesh B. 2013. Antimicrobial susceptibility associated with bloodstream infections in children: a referral hospital-based study. Braz.J.Infect.Dis. 17: 497-99.

26. Schaeffer AJ, Rajan N, Cao Q, Anderson BE, Pruden DL, Sensibar J and Duncan JL. 2001. Host pathogenesis in urinary tract infections. Int. J. Antimicrob. Agents. 17:245-51.

27. Shigemura K, Tanaka K, Okada H, Nakano Y, Kinoshita S, Gotoh A, Arakawa S and Fujisawa M. 2005. Pathogen occurrence and antimicrobial susceptibility of urinary tract infection cases during a 20year period (1983-2002) at a single institution in Japan. Jpn. J. infects. Dis.58:303-8. 